\title{
The Money Supply Process in Bangladesh: An Econometric Analysis
}

\section{Monir Uddin Ahmed ${ }^{1}$, Md. Moniruzzaman Muzib' ${ }^{2 *}$,Subrata Saha ${ }^{3}$}

${ }^{1}$ Assistant Professor, Department of Economics, Shahjalal University of Science and Technology University, Sylhet-3114, BANGLADESH

${ }^{2}$ Assistant Professor, Department of Economics, Mawlana Bhashani Science and Technology University, Santosh, Tangail-1902, BANGLADESH

${ }^{3}$ Lecturer, Department of Economics, Mawlana Bhashani Science and Technology University, Santosh, Tangail-1902, BANGLADESH

*Corresponding Contact:

Email: zamanmuzib@gmail.com

Cell Phone: +8801712719030

Key Words: Board money, Interest Rate, Bank rate, Remittance and Inflation

JEL Code: E31, E43, E51, E52

\section{INTRODUCTION}

The economy of Bangladesh suffers from many problems from both the supply and demand sides of the real economy. The monetary sector, particularly the management of the money, credit, interest rate and bank rate may also have significant implications for the problems facing the real sectors of the economy of the country. Bangladesh is one of the least developed countries in the world as it suffers from poverty, imperfection in both factor and product markets, continuous disequilibrium in the economy, deficient administrative structure, inappropriate tax structure, heavy dependence on external sector, lack of capital stock, and massive unemployment. The country is not only technologically and 
managerially inefficient but also underdeveloped in the transport, telecommunication, and energy sectors. A Huge amount of unemployment, low standard of living, low level of saving, a surplus of unskilled labor, acute balance of trade deficit and low growth rates are prevailing in the economy. Besides, political instability causes a serious problem for the economy. The country still doesn't have any effective governance system, which will ensure corporate governance and corporate social responsibility of the country. The money supply and its prudent management and control through the monetary policy pursued by the central bank of a country can play a significant role in the managing and controlling the real sector to achieve low inflation and unemployment and high economic growth. In economics, several alternative indicators such as $\mathrm{M}_{1}$ or $\mathrm{M}_{2}$ money are used as measures money supply in a country. $\mathrm{M}_{1}$ is the narrow money supply, which includes currency outside banks plus demand deposit, and the broad money $\mathrm{M}_{2}$ includes currency outside banks plus demand deposit plus saving deposit. Both $\mathrm{M}_{1}$ and $\mathrm{M}_{2}$ money can be significantly influenced by the amount of high-powered money, which is also known as the monetary base. This high-powered money consists of currencies in circulation and the bank reserves.

There are some studies on money supply and money multiplier both in developed and developing countries. For example, (Zaki, 1995) investigates whether monetary authorities in Egypt can control the money supply and finds the impossibility of such a procedure for the sample period of 1950 to 1990. (Islam, 2008) finds that currency-deposit ratio component in the multiplier model, net government borrowing and foreign asset components in reserve money (RM) are the major contributors to changes in money supply. (Sanusi, 2010) Examines the major drivers of the money supply from asset side in Ghana for the period of 1983-2006 using the money multiplier approach. He finds that until the mid-nineties, fiscal deficit financing was the major driver of the money supply process, while in the later years, changes in the net foreign assets of the Bank of Ghana, driven largely by foreign aid and remittances inflows, appear to be the cause of monetary expansion. Some earlier studies in this area include (Roberts and Margolis, 1976), (Khatkhate et. al., 1980), (Johannes and Rasche, 1981), and (Gauger, 1998). (Friedman, M. and Schwartz, A.J., 1963) Shows that the money supply is determined by the following three variables such as the stock of high-powered money, the ratio of deposit to reserve, the ratio of deposit to currency. However, (Tobin, 1965), disagrees with the monetarist approach to determine the money supply function. He argues that to express the stock of money regarding high-powered money, the reserve-deposit ratio and the currency-deposit ratio are showing an arithmetic tautology. (Kaldor, N., 1970). The Neo Monetarism criticizes the Monetarist view that the quantity of money is determined by the demand of the public and that the central bank will be successful if it wants to change the supply of money. The proponents of the (Keynesians, 1930s) argue that if the central bank tries to increase aggregate demand by open market purchase, it will not be possible. Because the public would not accept real cash balance more than their needs and portfolio requirements.

By the above discussion we will show that money supply is determined by the deposit interest rate, real interest rate, nominal interest rate, remittance, and bank rate. This study has a very limited objective, i.e. to estimate which variables determine the money supply in Bangladesh empirically and then examine how the supply of money can be managed better to improve the economy of Bangladesh. Though fiscal and monetary policy both is effective to improve the economy of our country despite this monetary policy is better and timesaving instrument. The main objective of the study is in the following:

- To determine the factors, that explain the money multiplier in Bangladesh; and

- To determine the co integration among the determinants of money multiplier 


\section{Methodology}

After independence, this study considers three years as transitional, hence unusual periods. Thus, the data from 1972-73 to 1974-75 considering as the transitional period has been dropped. One the other side due to lack of common base year, we have dropped the data from 1975-76 to 1984-85. Though we wanted to study from the 1971, we ended up starting our investigation from 1986.

Although Macroeconomic stability programs and structural adjustment processes started in the middle of eighties, due to various repression prevailing in the economy, financial liberalization on track in earnest in the 1990's. To make the study more up-to-date, we have taken the latest available data for which the study period extends up to 2008. As such study period is 1974 to 2010.

In our mathematical analysis at first we will show how $\mathrm{M}_{1}$ and $\mathrm{M}_{2}$ will be influenced by the Real interest rate, Nominal interest rate, Remittance, Inflation, Bank Rate and Deposit interest rate. Secondly, we will show how $\mathrm{M}_{1}$ and $\mathrm{M}_{2}$ will be affected by the Speed of adjustment that is equal to the difference between deposit interest rate and nominal interest rate. In our analysis mainly secondary data of the above variables has been employed for the study. The data are time series in nature. The main sources of data are Bangladesh Bureau of Statistics (BBS), World Data Index (WDI), Ministry of Finance, and Bangladesh Economic Review, various economics trends, Bangladesh Bank bulletin, Bangladesh Arthanaitic Samikhaya, Bangladesh Bank quarterly journals in which money supply is considered as the dependent variable in relevant equations, besides the aforesaid statistical test, we also test whether serially correlated errors are present or not. As such the study has computed Durbin-Watson statistics.

In our analysis, we will use multiple regression models and then we have presented and made an explanation of our findings. Mathematically, our model is looks like

$\mathrm{M}_{1}=\mathrm{f}($ dir,irs,inf,rir,br,rem)

$\mathrm{M}_{1}=\mathrm{f}($ dir,nir,inf,br,rem).

$\mathrm{M}_{2}=\mathrm{f}($ dir,irs,inf,rir,br,rem)

$\mathrm{M}_{2}=\mathrm{f}($ dir,nir,inf,br,rem).

Where,

$\mathrm{M}_{1}=$ narrow money supply, $\mathrm{M}_{2}=$ broad money supply, rir=real interest rate, nir= nominal interest rate, dir=deposit interest rate, rem=remittance, and $b r=b a n k$ rate.

\section{EMPIRICAL ANALYSIS}

By our data analysis, we have found the following result by using econometric model that is given in appendices is:

Table 1: The regression model of equation (1):

\begin{tabular}{|l|l|l|l|}
\hline Variable & Coefficient & Standard error & t-stat \\
\hline Constant & 19420.192 & 13879.202 & 1.3999 \\
\hline Dir & -0.203 & 988.327 & -1.915 \\
\hline Nir & -0.038 & 941.653 & -0.430 \\
\hline Inf & 0.003 & 1224.5 & 0.015 \\
\hline Rir & 0.049 & 1161.735 & 0.279 \\
\hline Br & 0.051 & 842.7 & 0.551 \\
\hline Rem & 0.990 & 0.000 & 13.291 \\
\hline R & 0.989 & & \\
\hline$R^{2}$ & 0.978 & & \\
\hline Durbin-Watson & 1.014 & & \\
\hline F-test & 116.744 & & \\
\hline
\end{tabular}


Here the dependent variable is $\mathrm{M}_{1}$. So the regression model shows that deposit interest rate (dir) and interest rate spread (irs) are negatively influenced on the narrow money supply while inflation (inf), real interest rate (rir) bank rate (br) and remittance (rem) have a positive influence on narrow money supply. The coefficient of the each variable shows that how these variable influence the dependent variable i.e. coefficient of remittance (0.990) means that if remittance rises by 1 taka then the narrow money supply rises by .99 taka. The economic interpretation of $\mathrm{R}^{2}$ is that these variables influences narrow money supply $\left(\mathrm{M}_{1}\right)$ by $97.8 \%$ which means that these are core variables to define $\mathrm{M}_{1} . \mathrm{D}=1.014$ means that there is a positive Autocorrelation among the disturbances. The $t$ value of remittance shows that it is statistically significant.

Table 2: The regression model of equation (2):

\begin{tabular}{|l|l|l|l|}
\hline Variable & Coefficient & Standard error & t-stat \\
\hline Constant & 17699.926 & 12967.198 & 1.365 \\
\hline Dir & -0.168 & 600.375 & -2.599 \\
\hline Nir & 0.005 & 1015.435 & 0.005 \\
\hline Inf & -0.031 & 301.776 & 0.101 \\
\hline Br & 0.041 & 796.558 & -0.745 \\
\hline Rem & 0.976 & 0.000 & 14.847 \\
\hline $\mathrm{R}$ & 0.989 & & \\
\hline $\mathrm{R}^{2}$ & 0.977 & & \\
\hline Durbin-Watson & 0.921 & & \\
\hline F-test & 147.110 & & \\
\hline
\end{tabular}

Here the dependent variable is also $\mathrm{M}_{1}$. So the regression model shows that deposit interest rate (dir) and inflation (inf) are negatively influenced on the narrow money supply while nominal interest rate (nir) bank rate (br) and remittance (rem) have positive an influence on narrow money supply. The coefficient of the each variable shows that how these variable influence the dependent variable i.e. coefficient of remittance (0.976) means that if remittance goes up by 1 taka then the narrow money supply rises by .976 taka. The economic interpretation of $\mathrm{R}^{2}$ is that these variables influence M1 by $97.7 \%$ which means that these are core variables to define $\mathrm{M}_{1} . \mathrm{D}=0.921$ means that there are positive Autocorrelation among the disturbances. The $t$ value of remittance shows that it is statistically significant.

Table 3: The regression model of equation (3):

\begin{tabular}{|l|l|l|l|}
\hline Variable & Coefficient & Standard error & t-stat \\
\hline Constant & 42595.422 & 58697.362 & 0.726 \\
\hline Dir & -0.179 & 4179.791 & -1.788 \\
\hline Nir & -0.053 & 3982.399 & -0.646 \\
\hline Inf & 0.058 & 5178.604 & 0.363 \\
\hline Rir & 0.115 & 4913.164 & 0.695 \\
\hline Br & 0.048 & 3563.913 & 0.544 \\
\hline Rem & 1.002 & 0.000 & 14.244 \\
\hline R & 0.990 & & \\
\hline$R^{2}$ & 0.980 & & \\
\hline Durbin-Watson & 0.744 & & \\
\hline F-test & 131.142 & & \\
\hline
\end{tabular}


Here the dependent variable is $\mathrm{M}_{2}$. So the regression model shows that deposit interest rate (dir) and interest rate spread (irs) are negatively influenced on the broad money supply while inflation (inf), real interest rate (rir) bank rate (br) and remittance (rem) have positive influence on broad money supply. The coefficient of the each variable shows that how these variable influence the dependent variable i.e. coefficient of real interest rate $(0.115)$ means that if real interest rate goes up by 1 percent then the broad money supply rises by 11.5 percent. The economic interpretation of $R^{2}$ is that these variables influence $M_{2}$ by $98 \%$ which means that these are core variables to define $\mathrm{M}_{2}$. $\mathrm{D}=0.744$ means that there is a positive Autocorrelation among the disturbances. The $t$ value of remittance shows that it is statistically significant.

Table 4: The regression model of equation (4):

\begin{tabular}{|l|l|l|l|}
\hline Variable & Coefficient & Standard error & t-stat \\
\hline Constant & 31657.279 & 55233.539 & 0.573 \\
\hline Dir & -0.129 & 2557.286 & -2.096 \\
\hline Nir & 0.022 & 4325.224 & 0.463 \\
\hline Inf & -0.032 & 1285.407 & -0.797 \\
\hline $\mathrm{Br}$ & 0.034 & 3392.924 & 0.403 \\
\hline Rem & 0.983 & 0.000 & 15.710 \\
\hline $\mathrm{R}$ & 0.990 & & \\
\hline $\mathrm{R}^{2}$ & 0.980 & & \\
\hline Durbin-Watson & 0.607 & & \\
\hline F-test & 162.866 & & \\
\hline
\end{tabular}

Here the dependent variable is also $\mathrm{M}_{2}$. So the regression model shows that deposit interest rate (dir) and inflation (inf) are negatively influenced on the broad money supply while nominal interest rate (nir) bank rate (br) and remittance (rem) have positive influence on broad money supply. The coefficient of the each variable shows that how these variable influence the dependent variable i.e. coefficient of remittance (0.983) means that if remittance goes up by 1 taka then the broad money supply rises by .983 taka. The economic interpretation of $\mathrm{R}^{2}$ is that these variables influence broad money supply $\left(\mathrm{M}_{2}\right)$ by $98 \%$ which means that these are core variables to define $\mathrm{M}_{2}$. $\mathrm{D}=0.607$ means that there is a positive auto correlation among the disturbances. The $t$ value of remittance shows that it is statistically significant.

\section{CONCLUSION}

The study has empirically estimated the supply of money function for Bangladesh using time series annual data from 1986-87 to 2008-2009 and utilizing the traditional linear regression analysis. If one wants to forecast the broad money for the country regarding individual variables, the remittance seems to play a very prominent role in the money supply process. Beyond this, it also appears that the real interest rate, bank rate, and inflation have significant impact on the broad money supply of Bangladesh. For the narrow money supply, remittance appears to have the most influence. However, the performance of the variables, deposit interest rate, and interest rate spread, came out with unexpected negative signs. These anomalies may be at least partially attributed to the presence of strong multicolinearity in the sample data and /or data problems. Since these components, M1 and M2 limit the degree of controllability of Bangladesh Bank over the money supply, the conduct of prudent monetary policy would crucially depend on taking into consideration the implications of changes in these key components. 


\section{REFERENCES}

Ahmed AA. 2009. The Effect of Timeliness Regulation of Corporate Financial Reporting: Evidence from Banking Sector of Bangladesh Accounting and Management Information Systems, 8, 216 - 235.

Ahmed AA. 2012. Disclosure of Financial Reporting and Firm Structure as a Determinant: A Study on the Listed Companies of DSE ASA University Review, 6, 43-60.

Ahmed, A. A. A. (2009), "Compliance of Financial Disclosure in Corporate Annual Reports of Banking Sector of Bangladesh", Published Ph. D Dissertation, Rajshahi University.

Ali, M.M, (2001) Determinants of Supply of and Demand for Money: A case study of Bangladesh. Student Ways, Dhaka, Bangladesh.

Awan, A., \& Imran, M. (2015). Factors Affecting Food Price Inflation in Pakistan. ABC Journal Of Advanced Research, 4(1), 74-88. doi:http://dx.doi.org/10.18034/abcjar.v4i1.595

Begum R, Ahmed AA and Neogy TK. 2012. Management Decisions and Univariate Analysis: Effects on Corporate Governance in Bangladesh Journal of Business Studies, 3, 87-115.

Developing Economies: The Venezuelan Case", in W. L. Coats, Money and Monetary Policy in Less Developed Countries, Pergaman Press Ltd, London.

Friedman, M. and Schwartz, A.J., (1963). "A Monetary History of the United States, 1867-1960". National Bureau of Economic Research Studies in Business Cycles, No.12, University Press, Princeton, USA.

Gauger, J., (1998) "Economic Impacts on the Money Supply Process," Journal of Macroeconomics, 20(3): 553-577.

Hassan, Basher, and Ihsan., (2004)."A Macroeconometric Model of the Bangladesh Economy and Its Policy Implications", The Journal of Developing Areas, Volume 38,

Islam, M.E., (2008) "Money Supply Process in Bangladesh: An Empirical Analysis", Bangladesh Bank's Working Paper Series 0805, Retrieved from www.bangladeshbank.org.bd

Johannes, J.M. and R.H. Rasche., (1981) "Can the Reserve Approach to Monetary Control really work?" Journal of Money, Credit and Banking, 13(3): 298:313.

Kaldor, N., (1970) The Neo Monetarism, Lloyds Bank Review, No.97

Khatkhate, D.R, Galbis. V.G and Villanueva. D.D, (1980) "A Money Multiplier Model for

Momen, A., (1992) "Money, structuralism and the International Monetary Fund: An auto regression assessment of controversy". The Bangladesh Development Studies, Vol. XX, No. 4.

Neogy TK and Ahmed AA. 2015. The Extent of Disclosure of Different Components of Disclosure Index: A Study on Commercial Banks in Bangladesh Global Disclosure of Economics and Business, 2, 100-110.

Osmani, S.R., Bakht, Z. and Anwaruzzaman, C., (1986). "The Impact of Fiscal policy on the monetary sector of Bangladesh". Bangladesh Institute of Development Studies, Research Report no. 50.

Oyejide, T. A. (1974). "Controlling money supply in Less developed countries: The Case of Nigeria", The Bangladesh Development Studies, Vol. XVI, No. 3.

Parikh, A. and Starmer, C., (1988). "The relationship between the money supply and prices in Bangladesh", The Bangladesh Development Studies, Vol. XVI, No. 3.

Quader MT, Neogy TK and Ahmed AA. 2010. Econometric Growth Rates Analysis of Basic Bank Limited in Bangladesh: An Evaluation Development Compilation, 4, 48-60.

Roberts, S.M. and M.S. Margolis., (1978). "Control of Money Stock with a Reserve Aggregate", Journal of Money, Credit and Banking, 8(4): 457:476.

Sanusi, A. R., (2010). "An Empirical Analysis of the Money Supply Process in Ghana: 1983-2006", Abuja Journal of Banking and Finance, 2(1): 115-128

Zaki, M. Y., (1995). "Forecasting the Money Multiplier and the Control of Money Supply in Egypt", Journal of Development Studies, 32(1): 97-111. 